\title{
The avian chorioallantoic membrane as an alternative tool to study medullary thyroid cancer
}

\author{
Nassim Ghaffari-Tabrizi-Wizsy*, Christina Angelika Passegger*, Laura Nebel, Fabian Krismer, \\ Gudrun Herzer-Schneidhofer, Gert Schwach and Roswitha Pfragner
}

Otto Loewi Research Center - Immunology and Pathophysiology, Medical University of Graz, Graz, Austria

Correspondence should be addressed to N Ghaffari-Tabrizi-Wizsy: nassim.ghaffari@medunigraz.at

*(N Ghaffari-Tabrizi-Wizsy and C A Passegger contributed equally to this work)

\begin{abstract}
Preclinical trials of medullary thyroid cancer (MTC) therapeutics require both in vitro and in vivo analyses. Human tumour xenografted rodent models, which are considered the 'gold standard' to study and validate the efficacy and toxicity of lead compounds before translation to clinical trials, are very expensive, subject to organismal variability and ethical controversies. The avian chorioallantoic membrane (CAM) assay provides an alternative versatile, cost-effective and ethically less objectionable short-term, in vivo model for reliable screening of drugs. In this work, we grafted two MTC cell lines and patient-derived MTC tumour samples onto the avian CAM and characterised the resulted tumours histologically and immunohistochemically. Our findings provide the evidence that the CAM assay is a suitable model for studying the pathophysiology of MTC and can even be used as in vivo system for drug testing.
\end{abstract}

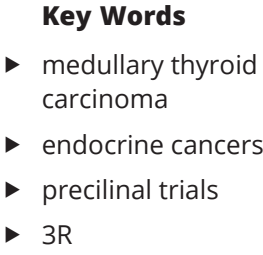

Endocrine Connections (2019) 8, 462-467

\section{Introduction}

Medullary thyroid cancer (MTC) is a rare thyroid tumour arising from neural-crest-derived parafollicular thyroid $\mathrm{C}$ cells, accounting for about 5-8\% of all thyroid cancers and may occur sporadic (70-80\% of cases) or hereditary (20-30\%) (1). In about $25 \%$ of cases, MTC is caused by inherited germline-activating mutations of the 'rearranged during transfection' (RET) proto-oncogene, which constitutively activates cellular signalling, resulting in persistent cell proliferation and MTC. Therefore, this oncogene represents a key player both in MTC pathogenesis in preclinical models and as molecular target for drugs inhibiting the action of pathogenic oncoproteins.

Mouse models are of fundamental importance to evaluate the efficacy of targeted therapy inhibiting oncoproteins. In addition to the murine models, other animal organisms for example, Drosophila, zebrafish and chick embryo have been used in the preclinical research on MTC (see 2 for review).

The avian chorioallantoic membrane assay serves as a short-term in vivo model, which can be easily used prior to costly, time-consuming and elaborate mouse models. The avian chorioallantoic membrane (CAM) assay has been utilised as a cancer model system for more than a century $(3,4,5,6,7)$.

Wide ranges of tumours, including thyroid cancers, have been studied using CAM $(8,9,10,11,12)$. Yalcin et al. showed that in the CAM, tetrac and tetrac NP inhibited tumour growth and tumour-associated angiogenesis of h-MTC cell line (13). We demonstrated the antitumourigenic effects of Shikonin on MTC-derived TT cell line grafted on CAM (8).

In this work, we show the applicability of CAM for MTC research more detailed. We grafted two MTC

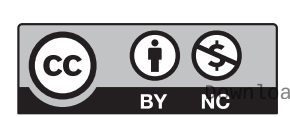

This work is licensed under a Creative Commons Attribution-NonCommercial 4.0 International License. ded from Bioscientifica.com at 04/26/2023 12:01:59AM 
cells lines (TT and OEE-III) as well as patient-derived MTC tissue samples onto the avian CAM, monitored their growth and morphologically characterised the resulting tumours.

\section{Materials and methods}

\section{Cell culture}

Human medullary thyroid cancer cell lines TT (obtained from the European Collection of Authenticated Cell Cultures (ECACC; Porton Down, Salisbury, UK) and OEE-III (established in our lab) (14) were cultivated in a humidified incubator at $5 \% \mathrm{CO}_{2}$ and $37^{\circ} \mathrm{C}$ in Ham's F12 (BioWhittaker, Lonza) supplemented with 10\% FBS foetal bovine serum (PAA) and 1\% penicillin/streptomycin (Biochrom).

\section{Patient and tumour samples}

MTCs from two patients were used for this study, which were preserved in cultivating medium containing $10 \%$ DMSO and stored in liquid nitrogen for 20 years. Tissues were examined immunohistochemically for calcitonin, carcinoembryonic antigen and neuroendocrine markers (chromogranin A, synaptophysin) prior freezing. Patients were treated surgically without any adjuvant treatment. Written informed consent was obtained from all patients. The study was approved by the Ethical Committee of the Medical University of Graz (\# 18-182 ex 06/07).

\section{CAM xenografts}

We performed the ex ovo CAM method according to Deryugina et al. (15): Fertilised white Lohmann chicken eggs (from local provider) were incubated at $37^{\circ} \mathrm{C}$ and $60 \%$ humidity. The egg shells were cracked on day 3 of embryonic development and the embryos were incubated in a sterile dish for further application. On day 10 of embryonic development, onplants with $1 \times 10^{6}$ TT or OEE-III cells, respectively, were resuspended in $10 \mu \mathrm{L}$ phosphate buffered saline (PBS) and mixed with an equal volume of Matrigel (BD Biosciences). Tumour tissue ( $2 \mathrm{~mm}$ pieces) were then grafted on the CAM of ex ovo-cultivated embryos using a silicon ring

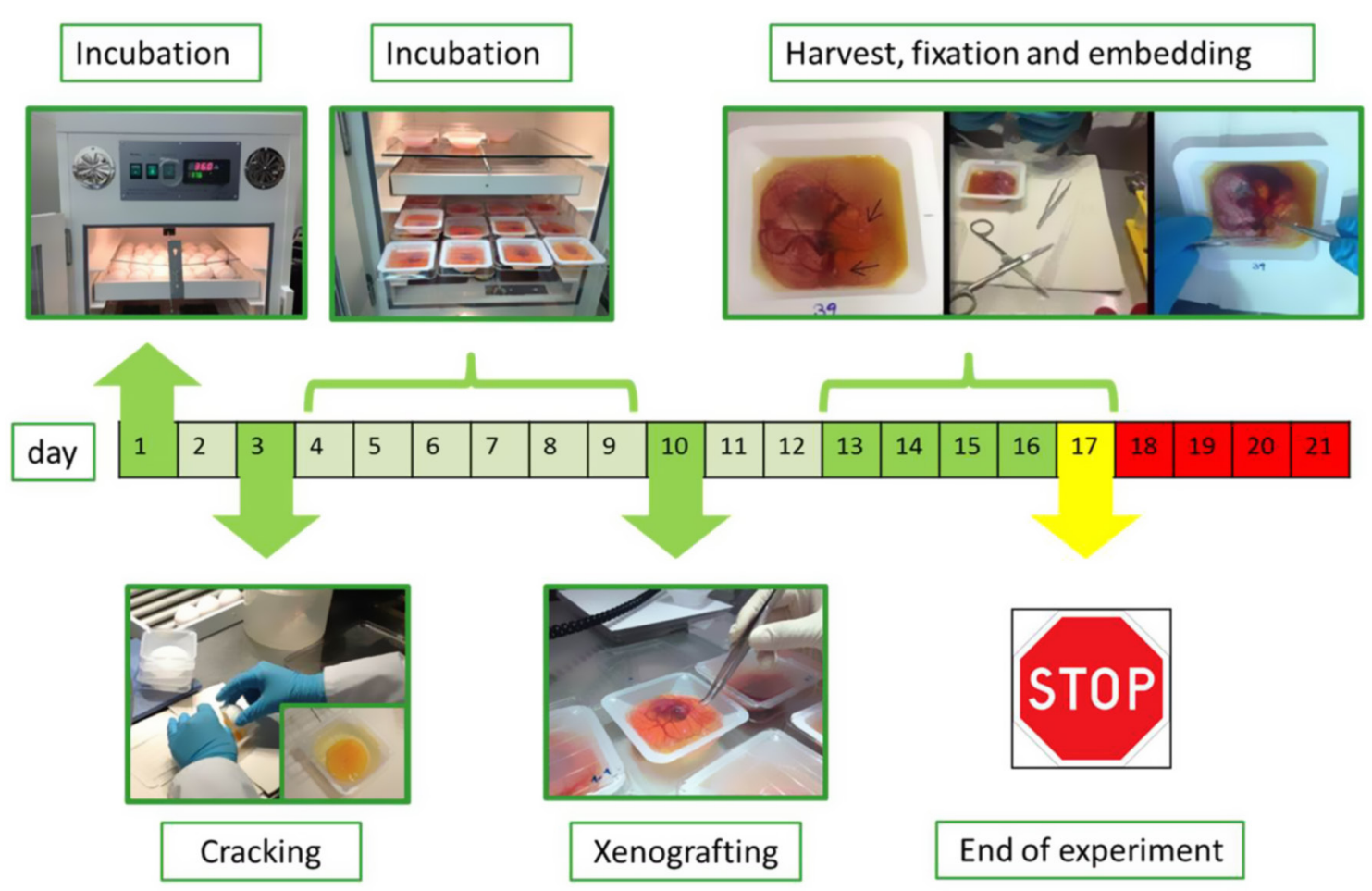

Figure 1

Schematic workflow of ex ovo CAM assay. Fertilised eggs were incubated for 3 days, the egg shell was then cracked into sterile dishes and incubated for 7 more days. Cells or tissues were applied on vascular branches of the CAM and incubated for additional 3 and 6 days, respectively. The grafts were then excised, followed by FFPE-tissue embedding and sectioning. The tumour morphology was analysed by histology and immunostainings.

https://ec.bioscientifica.com https://doi.org/10.1530/EC-18-0431 (c) 2019 The authors Published by Bioscientifica Ltd

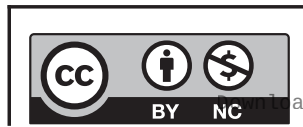

This work is licensed under a Creative Commons Attribution-NonCommercial 4.0 International License. ded from Bioscientifica.com at 04/26/2023 12:01:59AM 
A

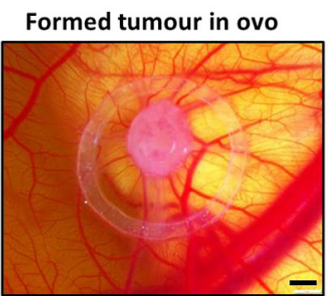

OEE-III

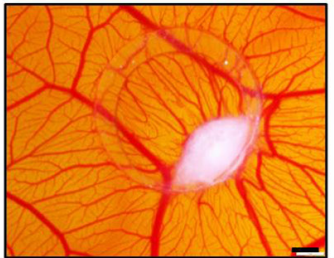

Excised topside

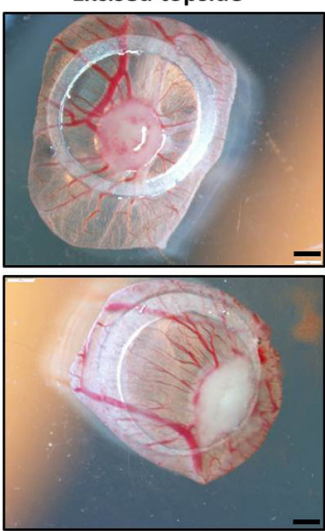

Excised underside

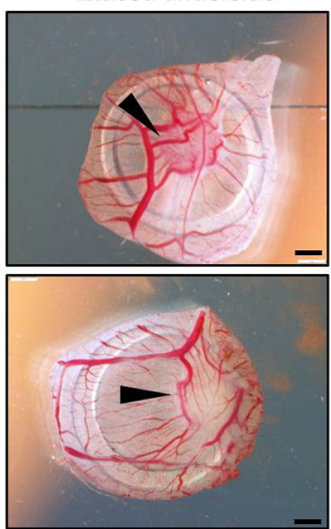

B

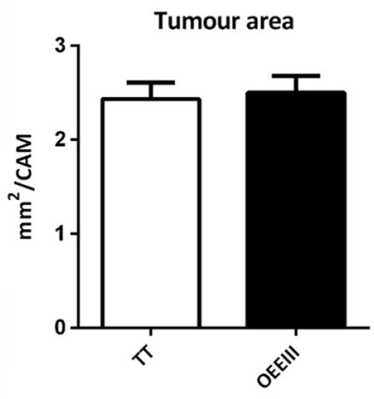

Figure 2

Photo-documentation of xenografted MTC cell lines, TT (upper panel) and OEE-III (lower panel) on day 3. (A) Both cell lines formed solid tumours 3 days upon placing the cells on the CAM surface, embryonic vessels developed into the tumours (arrows), bars $=1 \mathrm{~mm}$. (B) Tumour area per CAM was measured using ImageJ software. Results were plotted as mean \pm S.D. using GraphPad prism software ( $N=6$ tumours). Unpaired Student $t$-test was used for statistical analysis.

of $5 \mathrm{~mm}$ diameter as a barrier. Tumour formation was allowed to happen and development of cell xenografts was monitored by photo-documentation (Olympus SZX16) for 3-6 days (Fig. 1). Tumours with the CAM were then excised, photographed and tumour area was quantified using ImageJ software. Samples were fixed in $4 \%$ paraformaldehyde (overnight, room temperature) followed by FFPE-tissue embedding.

In the EU the CAM assay is not declared as an animal experiment by law and even fulfils the 3R criteria
A

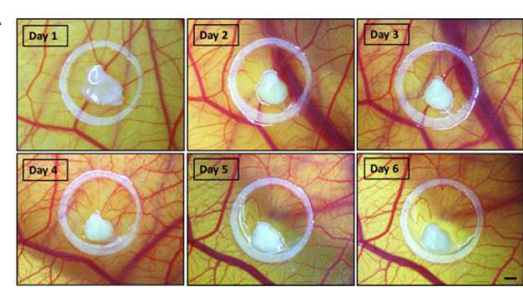

C
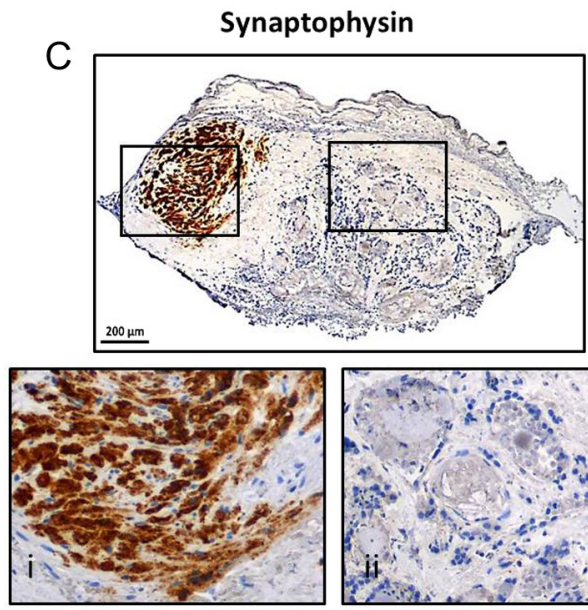

MTC

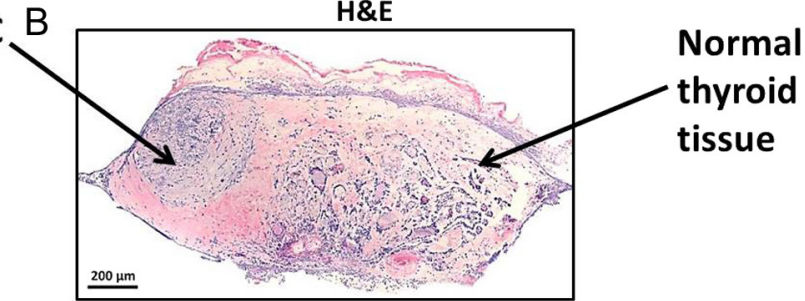

D
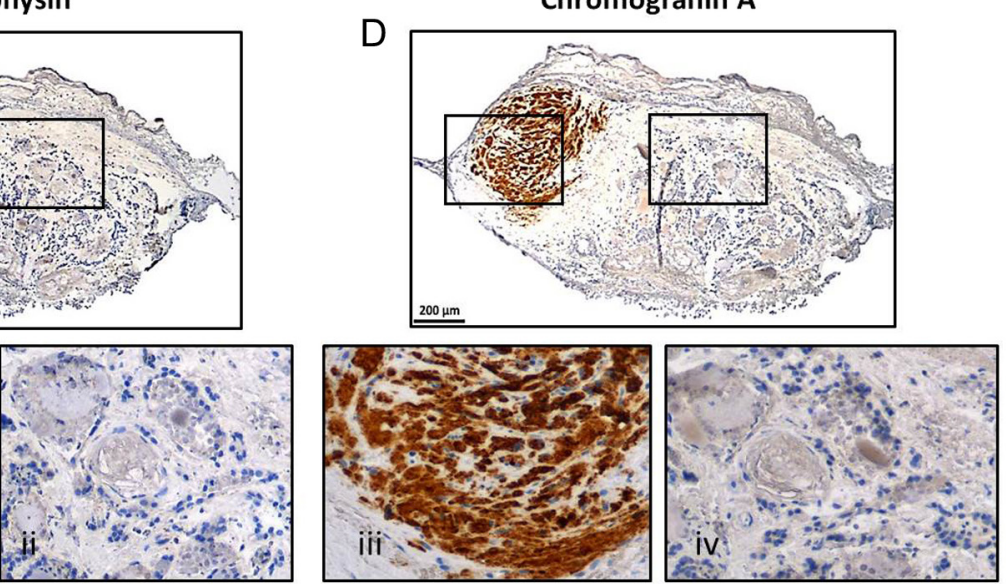

\section{Figure 3}

MTC primary tumour tissue grafted on the CAM retained to express specific tumour markers. (A) Tumour tissue grown on the CAM for 6 days, bar $=1 \mathrm{~mm}$. (B) Subsequent histological analyses showed that the patient sample was composed of MTC and healthy thyroid tissue. The tumour tissue was positive for tumour markers synaptophysin ( $C$ and $i)$ and chromogranin $A(D$ and iii), whereas surrounding tissue (ii and iv) showed non-pathological thyroid morphology.

$\begin{array}{lr}\text { https://ec.bioscientifica.com } & \text { (c) } 2019 \text { The authors } \\ \text { https://doi.org/10.1530/EC-18-0431 } & \text { Published by Bioscientifica Ltd }\end{array}$

This work is licensed under a Creative Commons Attribution-NonCommercial 4.0 International License. ded from Bioscientifica.com at 04/26/2023 12:01:59AM 

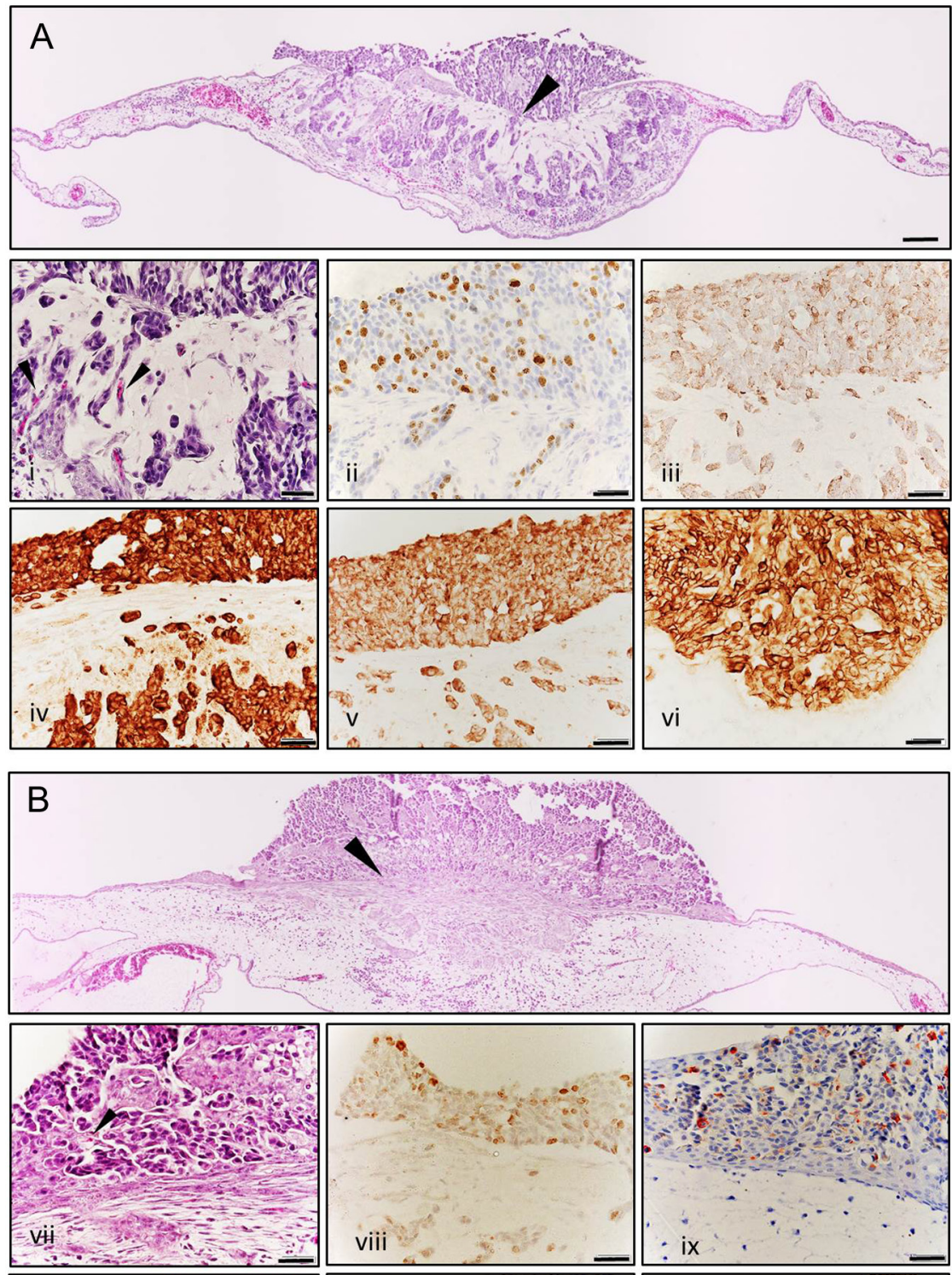

\section{Figure 4}

Histology and immunohistochemical

characterisation of TT (upper panel, A and i-vi) and OEE-III tumours (lower panel, B and vii-xii) grown on CAM. (A and B) Morphological analysis of H\&E-stained tissue sections shows the invasive outgrowth (arrows) of tumour cells into the surrounding CAM stromal tissue (100x magnification, bars $100 \mu \mathrm{M}$ ). (i and vii) Closer look to H\&E stained tissue (400x) reveals that tumours are composed of clusters of small, round cells with round nuclei. Neoangiogenesis can be observed within the tumour mass (arrows). Nuclear staining of Ki- 67 shows that both cell lines are mitotic active on the CAM (ii, viii). The tumours retain their MTC and neuroendocrine specific markers: calcitonin (iii and ix), chromogranin A (iv and $x$ ), synaptophysin ( $v$ and $x i)$ and carcinoembryonic antigen (vi and xii).

(replacement, reduction, refinement), and therefore, does not require an ethical approval.

\section{Histology}

Tissue sections of $5 \mu \mathrm{m}$ were stained with haematoxylin/ eosin or analysed immunohistochemically according to the protocol (Mouse- and Rabbit-specific HRP/DAB Detection
IHC Kit, Abcam). Shortly, sections were de-paraffinised, rehydrated and upon blocking of unspecific binding, incubated with primary antibodies for $1 \mathrm{~h}$ at room temperature. Detection of target antigens was performed via streptavidin-peroxidase-mediated colour reaction of AEC or DAB. Following primary antibodies were used: Ki-67 (Dako, clone M7240, 1:80), calcitonin (Novus, clone SP17, 1:10) synaptophysin (Pierce Thermo Scientific, 1:80), https://ec.bioscientifica.com https://doi.org/10.1530/EC-18-0431 (c) 2019 The authors Published by Bioscientifica Ltd

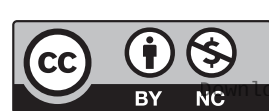

This work is licensed under a Creative Commons Attribution-NonCommercial 4.0 International License. ded from Bioscientifica com at 04/26/2023 12:01:59AM 

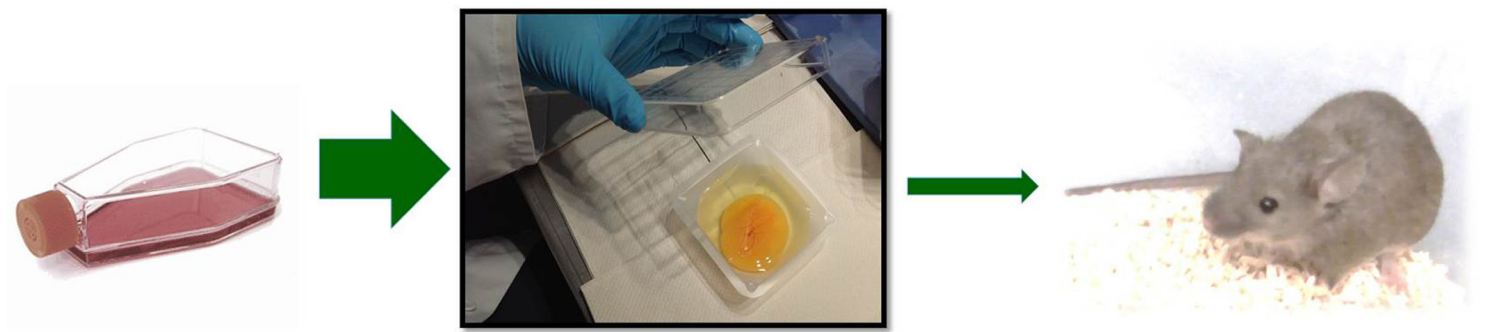

Figure 5

Chick before the mouse. The avian chorioallantoic membrane assay can be considered as an in vivo model between cell-based assays and rodent model.

chromogranin A (Pierce Thermo Scientific, 1:500) and carcinoembryonic antigen (Dako, cloneII-7, 1:1000). Images were taken on an Olympus BX53.

\section{Results and discussion}

\section{In vivo observation}

Both cell lines (TT and OEE-III) formed solid and vascularised tumours within 3 days when grafted on CAM (Fig. 2A). TT and OEE-III revealed similar and reproducible $\left(\mathrm{N}=6\right.$ each) growth patterns. The tumour area $\left(\mathrm{mm}^{2}\right)$ was determined by ImageJ (Fig. 2B).

The tumour samples used in this study have been stored in liquid nitrogen for two decades, yet, they still were alive and able to grow on CAM (Fig. 3A).

\section{Histological and immunohistological analysis}

At day 3 post transplantation, TT and OEE-III tumours were excised, fixed, paraffin embedded and stained for haematoxylin and eosin. Invasion of MTC cells from the primary onplant site into the surrounding CAM tissue and interaction with the CAM stromal tissue could be observed for both cell lines. Within the tumour, TT and OEE-III cells on CAM appeared small and round shaped alike the MTC tissues shown in pathology textbooks and papers (Fig. 4) (16). Using immunohistochemistry method (IHC) with Ki-67, we found TT and OEE-III cells to be mitotic active; in our recent paper we demonstrated that treatment of TT cells grown on CAM led to decrease of Ki67 cells by inducing apoptosis, showing the suitability of the method for drug screening (8). Moreover, TT and OEE-III cells grown on CAM retained to express specific markers for MTC and neuroendocrine tumours, for example calcitonin, chromogranin A, synaptophysin (p-38) and carcinoembryonic antigen (Fig. 4i, ii, iii, iv, v, vi, vii, viii, ix, $x, x i$ and $x i i)$.
Patient-derived MTC tissue samples were grafted for 6 days on CAM and then processed for histological analysis (Fig. 3B). The samples revealed to stay alive and were connate to the CAM without visible growth; however, they continue to express neuroendocrine-specific markers synaptophysin and chromogranin A (Fig. 3C and D).

\section{Discussion}

The avian chorioallantoic membrane facilitates the development of characteristic MTC tumours and provides a supporting microenvironment with blood vessels and stromal tissue. Different to cell culture-based assays, this technique allows detecting invasion and angiogenesis. Other advantages are the lack of immune system and the possibility to easily study therapeutic effects on tumour growth and expression of signalling molecules. A further advantage is that an expensive animal house is not necessary. CAM assay can be performed in a laboratory room equipped with incubators.

The major drawbacks of the method are that the observation time is limited to about 3-7 days following implantation and that in spite of the immature immune system of the chick embryo nonspecific inflammatory reaction may occur if experiments are extended after 15 days of incubation $(15,17,18,19)$. Therefore, this technique can be used only for short-term in vivo studies; nonetheless, it can serve to evaluate results obtained in cell culture for new therapeutics for MTC.

\section{Conclusion}

We conclude that CAM assay is a reliable alternative to rodent models, in terms of 3R (replacement, reduction, refinement) at least prior to work with mouse system (Fig. 5). Therefore, CAM assay could serve as a preclinical tool for seeking drugs against MTC and might help to increase the power and speed of the development of new drugs.

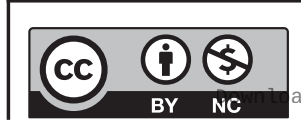

This work is licensed under a Creative Commons Attribution-NonCommercial 4.0 International License. ded from Bioscientifica.com at 04/26/2023 12:01:59AM via free access 
Finally, the experimental tumour model on the CAM can be adapted for other malignant thyroid tumours such as papillary and follicular thyroid carcinomas.

\section{Declaration of interest}

The authors declare that there is no conflict of interest that could be perceived as prejudicing the impartiality of the research reported.

\section{Funding}

This research did not receive any specific grant from any funding agency in the public, commercial or not-for-profit sector.

\section{Author contribution statement}

N G T W, C A P, L N, G H S and F K performed the lab work, N G T W designed the research study, $R P$ and G S provided OEE-III cell line. N G T W and L N analysed the data. N G TW and C A P wrote the paper.

\section{Acknowledgments}

The authors thank SFL Technologies (Stallhofen, Austria) for Olympus microscopes used in this study.

\section{References}

1 Schlumberger M, Carlomagno F, Baudin E, Bidart JM \& Santoro M. New therapeutic approaches to treat medullary thyroid carcinoma Nature Clinical Practice Endocrinology and Metabolism $2008422-32$. (https://doi.org/10.1038/ncpendmet0717)

2 Vitale G, Gaudenzi G, Circelli L, Manzoni MF, Bassi A, Fioritti N, Faggiano A, Colao A \& NIKE Group. Animal models of medullary thyroid cancer: state of the art and view to the future. EndocrineRelated Cancer 201724 R1-R12. (https://doi.org/10.1530/ERC-160399)

3 DeBord LC, Pathak RR, Villaneuva M, Liu HC, Harrington DA, Yu W, Lewis MT \& Sikora AG. The chick chorioallantoic membrane (CAM) as a versatile patient-derived xenograft (PDX) platform for precision medicine and preclinical research. American Journal of Cancer Research 20188 1642-1660.

4 Kain KH, Miller JW, Jones-Paris CR, Thomason RT, Lewis JD, Bader DM, Barnett JV \& Zijlstra A. The chick embryo as an expanding experimental model for cancer and cardiovascular research. Developmental Dynamics 2014243 216-228. (https://doi. org/10.1002/dvdy.24093)

5 Murphy JB. Transplantability of tissues to the embryo of foreign species: its bearing on questions of tissue specificity and tumor immunity. Journal of Experimental Medicine 191317 482-493. (https://doi.org/10.1084/jem.17.4.482)
6 Ribatti D. The chick embryo chorioallantoic membrane (CAM). A multifaceted experimental model. Mechanisms of Development 2016 141 70-77. (https://doi.org/10.1016/j.mod.2016.05.003)

7 Ribatti D. The chick embryo chorioallantoic membrane as a model for tumor biology. Experimental Cell Research 2014328 314-324. (https://doi.org/10.1016/j.yexcr.2014.06.010)

8 Hasenoehrl C, Schwach G, Ghaffari-Tabrizi-Wizsy N, Fuchs R, Kretschmer N, Bauer R \& Pfragner R. Anti-tumor effects of shikonin derivatives on human medullary thyroid carcinoma cells. Endocrine Connections 20176 53-62. (https://doi.org/10.1530/EC-16-0105)

9 Jia W, Gao XJ, Zhang ZD, Yang ZX \& Zhang G. S100A4 silencing suppresses proliferation, angiogenesis and invasion of thyroid cancer cells through downregulation of MMP-9 and VEGF. European Review for Medical and Pharmacological Sciences 201317 1495-1508.

10 Kalhori V, Magnusson M, Asghar MY, Pulli I \& Tornquist K. FTY720 (Fingolimod) attenuates basal and sphingosine-1-phosphate-evoked thyroid cancer cell invasion. Endocrine-Related Cancer 201623 457-468. (https://doi.org/10.1530/ERC-16-0050)

11 Pinto N, Prokopec S, Vizeacoumar F, Searle K, Lowerison M, Ruicci K, Yoo J, Fung K, MacNeil D, Lacefield C, et al. Lestaurtinib is a potent inhibitor of anaplastic thyroid cancer cell line models. PLoS One 2018 13 e0207152. (https://doi.org/10.1371/journal.pone.0207152)

12 PópuloH, Nunes B, Sampaio C, Batista R, Pinto M, Gaspar T, Miranda-Alves L, Cai RZ, Zhang XY Schally AV, et al. Inhibitory effects of antagonists of Growth Hormone-Releasing Hormone (GHRH) in thyroid cancer. Hormones and Cancer 20178 314-324.

13 Yalcin M Dyskin E, Lansing L, Bharali DJ, Mousa SS, Bridoux A, Hercbergs AH, Lin HY, Davis FB, Glinsky GV, et al. Tetraiodothyroacetic acid (tetrac) and nanoparticulate tetrac arrest growth of medullary carcinoma of the thyroid. Journal of Clinical Endocrinology and Metabolism 201095 1972-1980. (https://doi. org/10.1210/jc.2009-1926)

14 Flicker K, Ulz P, Hoger H, Zeitlhofer P, Haas OA, Behmel A, Buchinger W, Scheuba C, Niederle B, Pfragner R, et al. Highresolution analysis of alterations in medullary thyroid carcinoma genomes. International Journal of Cancer 2012131 E66-73. (https:// doi.org/10.1002/ijc.26494)

15 Deryugina EI \& Quigley JP. Chick embryo chorioallantoic membrane model systems to study and visualize human tumor cell metastasis. Histochemistry and Cell Biology 2008130 1119-1130. (https://doi. org/10.1007/s00418-008-0536-2)

16 Schmid KW. Histopathology of C cells and medullary thyroid carcinoma. Recent Results in Cancer Research 2015204 41-60.

17 Martowicz A, Kern J, Gunsilius E \& Untergasser G. Establishment of a human multiple myeloma xenograft model in the chicken to study tumor growth, invasion and angiogenesis. Journal of Visualized Experiments 201599 e52665. (https://doi.org/10.3791/52665)

18 Ribatti D \& Tamma R. The chick embryo chorioallantoic membrane as an in vivo experimental model to study human neuroblastoma. Journal of Cellular Physiology 2018234 152-157. (https://doi. org/10.1002/jcp.26773)

19 Staton CA, Reed MW \& Brown NJ. A critical analysis of current in vitro and in vivo angiogenesis assays. International Journal of Experimental Pathology 200990 195-221. (https://doi.org/10.1111/ j.1365-2613.2008.00633.x)

Received in final form 14 January 2019

Accepted 26 March 2019

Accepted Preprint published online 26 March 2019 https://ec.bioscientifica.com https://doi.org/10.1530/EC-18-0431 (c) 2019 The authors Published by Bioscientifica Ltd

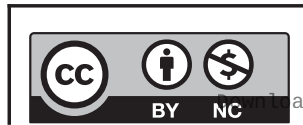

This work is licensed under a Creative Commons Attribution-NonCommercial 4.0 International License. ded from Bioscientifica.com at 04/26/2023 12:01:59AM 